\title{
Assessment methodology for the prediction of landslide dam hazard
}

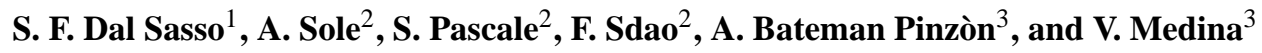 \\ ${ }^{1}$ Consortium of Italian Universities for Hydrology (CINID), Potenza, Italy \\ ${ }^{2}$ Engineering School, University of Basilicata, Potenza, Italy \\ ${ }^{3}$ Sediment Transport Research Group (GITS), Technical University of Catalonia (UPC), Barcelona, Spain \\ Correspondence to: A. Sole (aurelia.sole@unibas.it)
}

Received: 19 July 2013 - Published in Nat. Hazards Earth Syst. Sci. Discuss.: 17 October 2013

Revised: 21 January 2014 - Accepted: 27 January 2014 - Published: 12 March 2014

\begin{abstract}
This paper represents a contribution to the study of hazard caused by the interaction between landslides and river courses. The effects of such interferences are often catastrophic and could include the formation of upstream lakes, potential dam failure, river bed dynamics and morphological alterations. These scenarios could be substantially reduced if it was possible to predict the eventuality that a moving landslide would block the river. This is a complex topic because it involves composite geomorphic phenomena concerning both hillslope and river systems and their interpretation, through model approaches, is still under development and testing. In this study, a methodology developed in the framework of European Research Project IMPRINTS (FP7) was adopted and integrated in order to identify the areas of triggering and propagation of landslides and to characterize the possible scenarios of the interaction with river networks. Different deterministic and probabilistic approaches, calibrated using a case test in the middle valley of the Noce River in Basilicata (Italy), were applied and compared at basin scale.
\end{abstract}

\section{Introduction}

The interference between landslide and river courses is a topic of great relevance, because to date many catastrophic events have occurred in the world as a consequence of breaching of dams produced by landslides (Schuster and Costa, 1986; Costa and Schuster, 1988). Damming the river may cause the formation of upstream backwater, natural dam evolution, upstream and downstream flooding, initiation of other landslides and debris flows, river bed dynamics and channel instability (Swanson et al., 1985; Casagli and Ermini, 1999).
The interpretation of these phenomena is a complex topic, because of the numerous variables involving both hillslope and river dynamics at the same time. The phenomenon, though well studied, is still not consolidated into an accredited theory and is particularly suited to the development of scientific research, especially in the modeling field because the hydrodynamic interference between landslides and rivers and the dam creation has not been sufficiently studied.

The main purpose of the literary analysis is to forecast the main scenarios connected with a damming episode. These studies take into account the landslide dam inventory that represents the fundamental tool for the identification of the role played by hillslope and river systems. Most of them refer to the database of damming episodes that have occurred worldwide (Costa and Schuster, 1991) and primarily in the Italian territory (Nicoletti et al., 1993; Casagli and Ermini, 1999; Nicoletti and Parise, 2002; Crosta et al., 2004).

The study of the possibility that a moving landslide could block a river can be reached starting from quantitative assessments of landslide hazard that usually employ empirical, heuristic, deterministic, or statistical approaches (Korup, 2005). With reference to the dam creation, several authors, using a data set of landslide dam phenomena distributed worldwide, have proposed some geomorphic indexes to forecast landslide dam behavior, which take into account mainly geomorphic variables characterizing both the landslide and the river channel. Currently, the geomorphic approach is widely used also to predict dam evolution from the combination of variables identifying both dam and river (Swanson et al., 1986; Costa and Schuster, 1988; Casagli and Ermini, 1999; Ermini and Casagli, 2003; Korup, 2004). Moreover, the flood hazard related to the failure of natural dams is generally analyzed through deterministic models that simulate 

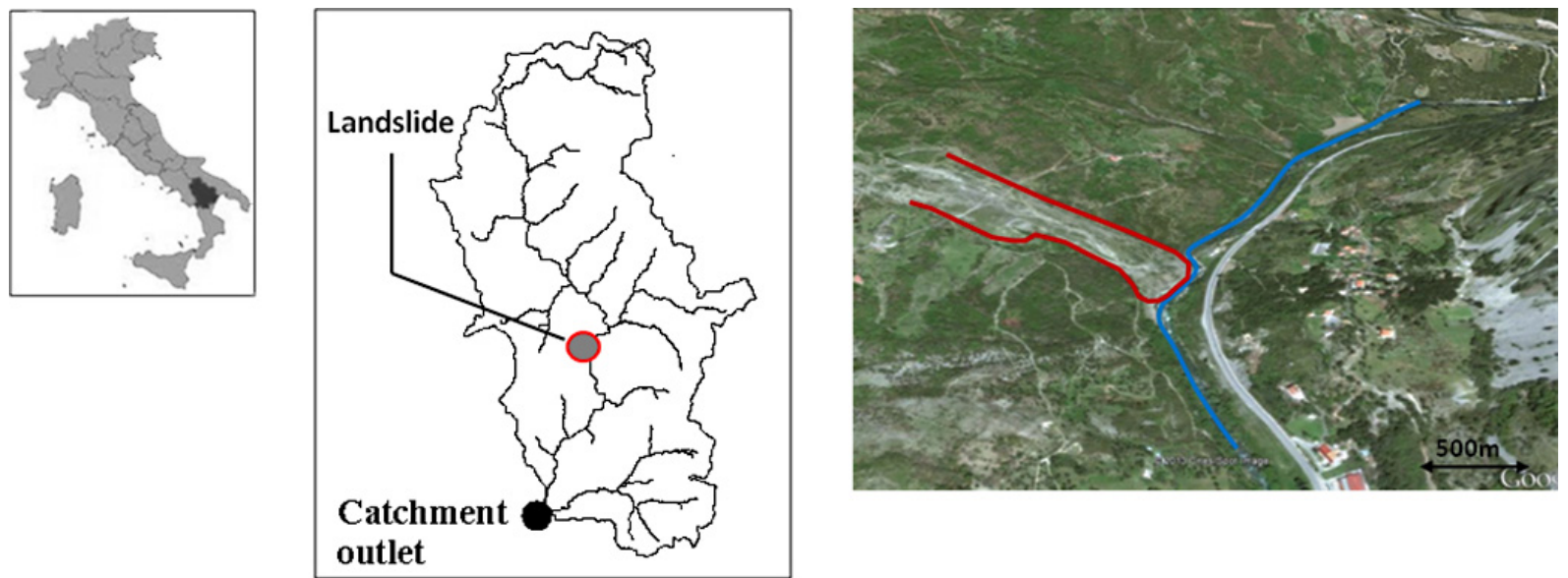

(a)

(b)

Fig. 1. (a) Study catchment and landslide location. (b) 3-D view of the landslide-river interference.

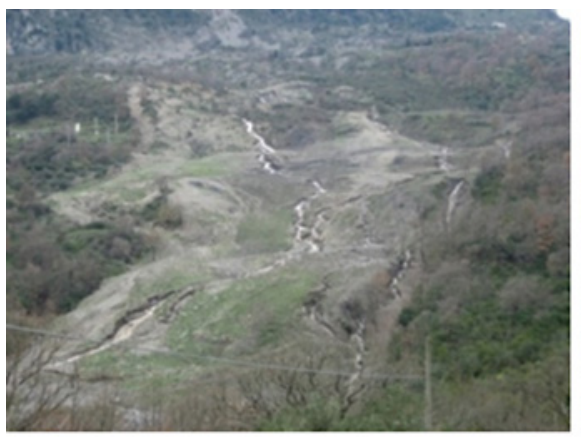

(a)

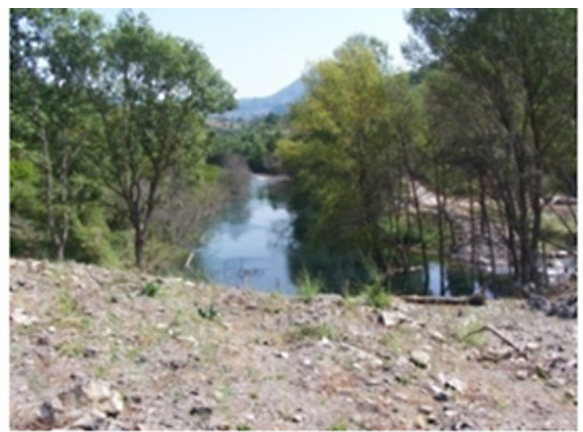

(b)

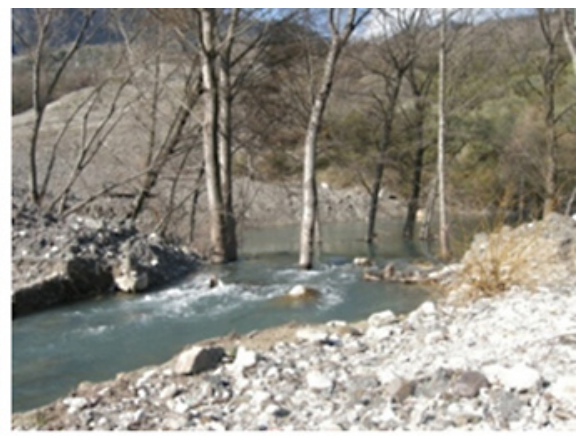

(c)

Fig. 2. (a) Landslide body. (b) Backwater lake upstream. (c) Dam-emptying process.

the dam break and estimate the hydrographs resulting from dam failures (Fread, 1991; Davies et al., 2007).

The objective of this study is to assess a methodology to predict the possibility that moving landslides could block a river, using different and more complex methods, from empirical approaches to dynamic ones. The models, calibrated in a case study on the Noce river in the Basilicata region (Italy), were applied at the basin scale, allowing one to assess preliminary and final hazard maps of landslide dams in the study catchment.

\section{Case study}

The case study is the interaction between a landslide and a narrow gravel-bed reach in the middle valley of the Noce River (total catchment area $413 \mathrm{~km}^{2}$ ), located in the Trecchina territory in SW Basilicata (Fig. 1a, b). The Zillona landslide mobilized along the right side slope of the basin (Fig. 2a) and produced the partial (in July 2007) and, later on (in November 2007), the total blockage of the water course, for $120 \mathrm{~m}$ of its length, with the formation of a small backwater lake upstream (Fig. 2b). The floods avoided the landslide bottom, producing an avulsion with the incision of a bend on the left floodplain, thus favoring the dam-emptying process (Fig. 2c).

The combined effects produced a new river morphological configuration with a progressive lowering of the floodplain (Fig. 3a, b). This highlighted cyclopean boulders next to the outside bank of the bend, probably belonging to an ancient mass movement on the left side of the hillslope (Fig. 3c). The landslide interference also induced morpho-hydrodynamic changes in the upstream and downstream reaches, because of the flow slowdown and deposition of sediments coming from upstream, forming bar sequences and armoring bed structures. 


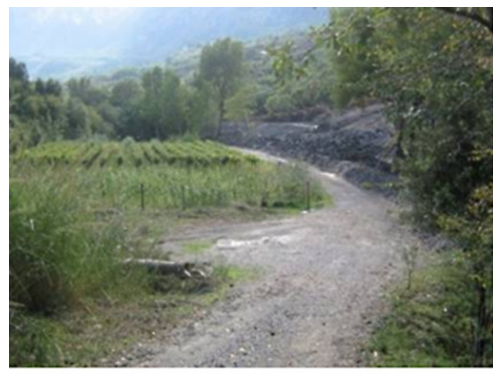

(a)

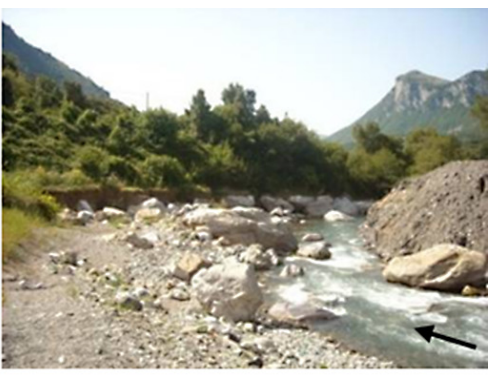

(b)

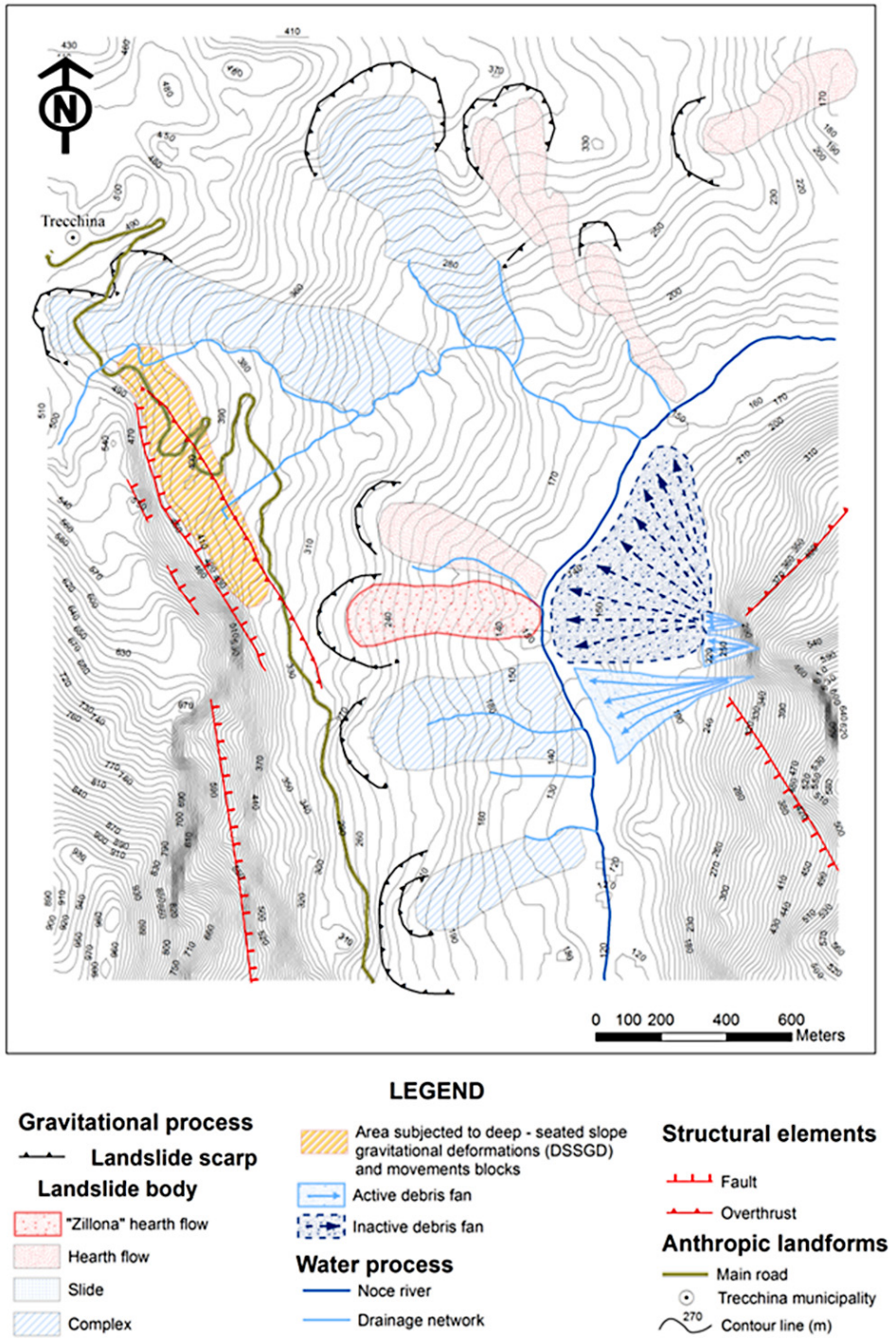

(c)

Fig. 3. Floodplain in the 2007 pre-landslide (a) and post-landslide (b) phases. (c) Geomorphological map of the Parrutta area.

\subsection{Geological setting}

The Zillona landslide is located on the western side of the Parrutta spring and south of the town of Trecchina. The study area is characterized by a complex geological and structural setting. In this area carbonate deposits related to the M. Bulgheria Verbicaro and Alburno Cervati units and blackish siliceous marls and argillites from the Liguride unit (Fig. 3c) crop out. The structural relationship between these geological formations consists of the overthrusting of the 


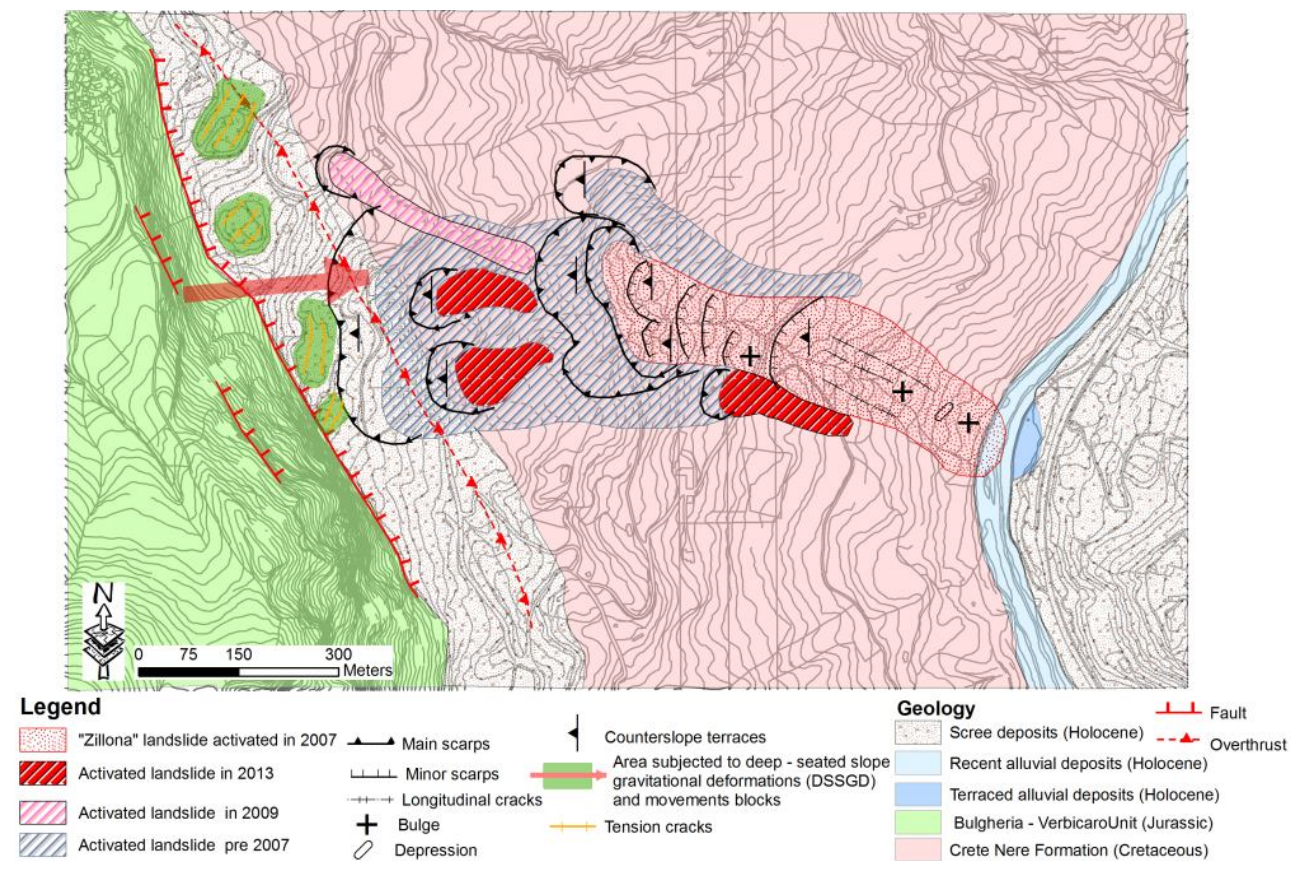

Fig. 4. Geomorphological map of the Zillona landslide.

M. Bulgheria Verbicaro unit on the Liguride unit and of the latter on the Alburno Cervati unit.

The Bulgheria Verbicaro unit (Jurassic) is constituted of a carbonate succession of dolomitic limestones and dolomites at the base passing upward into an alternation of limestones, calcilutites and calcarenites. These lithologies are located in the western part of the studied area, on the upper part of the right side of the Noce Valley.

The Alburno Cervati unit (Cretaceous) is also composed of a carbonate complex similar to the previous one, and is located on the high slope of the Noce River. All these geological formations are well stratified and intensely deformed and fractured.

The Liguride unit (Cretaceous-Lower Eocene) consists primarily of the clay-marl complex, showing generally a disorganized structure due to the intense tectonic processes that have affected this portion of the chain. This geological formation characterizes primarily the Zillona landslide on the lower right slope of the Noce River.

The original structural arrangements of the units described have been modified by strike-slip tectonic movements along the Pollino line during the Pleistocene. The Parrutta area is the result of these geomorphic activities and has the characteristics of a small pull-apart type basin, a tectonic depression oriented in the NS direction, bordered by faults with a predominantly vertical component.

\subsection{Geomorphology of the Zillona landslide}

The slope studied is strongly affected by the geomorphological effects of an intense morpho-gravitational dynamics char- acterized by large and complex mass movements and deep seated gravitational phenomena (DGPV). These phenomena are located in the upper portion of the slope and consist of wide and deep lateral spreading involving large blocks of limestone marl (Bulgheria Verbicaro unit), disarranged and tilted. The landslide studied involves the southern edge of this area of deformation.

The Zillona landslide is an ancient, complex and still active rototranslational slide that evolved into a large earthflow in 2007 (Cruden and Varnes, 1996; Di Maio et al., 2009). Involving the "Crete Nere" formation from the Liguride unit, it is approximately $650 \mathrm{~m}$ long, $130-160 \mathrm{~m}$ wide, and extends between 275 and $130 \mathrm{~m}$ a.s.l. (Noce River), with an average slope of about $13^{\circ}$.

Accurate in situ geological and geomorphological survey, aerial photo analysis and interpretation of geologic data related to eleven boreholes performed throughout the landslide body made it possible to define the main geomorphological features and state of activity of the landslide, particularly in its three different areas (source area, flow channel and accumulation area). The collected information, together with the results of the new geomorphological survey, allow us to obtain a better definition of the geological and geomorphological features of the landslide; some reconstructions are shown in Fig. 4.

Along the main body of the landslide there are several secondary scarps, morphological depressions, and minor surface landsliding; in addition, a wide counter-sloping landslide terrace and creeping evidence can be observed. 
The source area of the large earthflow is a multiple and retrogressive roto-translational slide, largely emptied and actually showing a concave shape. The main scarp, at an elevation of about $300 \mathrm{~m}$ a.s.l., is semicircular and is involved in rockfalls and small rockslides.

The source area is almost entirely covered by debris deposits of disjointed limestone and marl blocks immersed in a fine-grained matrix. In the eastern part of the source zone, a long and narrow debris flow is currently active, and the same happens for another debris flow to the east of the source zone.

The flow channel, which is probably placed on a preexisting drainage line, extends between 275 and $140 \mathrm{~m}$ a.s.1. and has an average slope of $13^{\circ}$. It is about $545 \mathrm{~m}$ long and the width varies from $110 \mathrm{~m}$ to $140 \mathrm{~m}$. It is delimited by two evident flanks. The accumulation zone shows a typical fan shape with an average slope of $6^{\circ}$. It is about $100 \mathrm{~m}$ long and $120 \mathrm{~m}$ wide. The landslide toe is located in the bed of the Noce River.

At present, some evidence of activity is visible in the same areas involved in the reactivation of 2007.

\section{Methodological approach}

A methodology, developed in the framework of the project IMPRINTS - IMproving Preparedness and RIsk maNagemenT for flash floods and debriS flow events - FP7 (Bregoli et al., 2010), was integrated in order to identify possible river network areas affected by landslide dams. This is a multilevel method, consisting of a basic and an advanced level, that uses more complex models to identify landslide dams and potential scenarios through geometrical and dynamic approaches (Fig. 5). The methodology is composed of three phases of investigation:

1. estimation of the volume potentially mobilized by a given value of precipitation with an assigned return period (initiation models: deterministic approach);

2. definition of the invasion areas and of the resulting energy (propagation and deposition models: stochastic and numerical models);

3. definition of landslide-river interference scenarios (deterministic approach: geomorphic indexes).

\subsection{Initiation models}

In this study, the SHALSTAB method (Montgomery et al., 1994), resulting from the combination of a slope stability model and a hydrological model, was applied in each level of the methodology only to assess shallow-landslide susceptibility in the catchment.

The model is based on the hypothesis that steady-state conditions are reached after a rainfall having constant intensity and indefinite duration. Assuming completely saturated material, the relation between rainfall and soil transmissivity may be derived for every cell of the DEM, as the result of the following expression:

$$
\frac{q}{T}=\frac{\sin \alpha}{(a / b)}\left(\left(\frac{c^{\prime}}{\rho_{\mathrm{w}} g z \cos ^{2} \alpha \tan \phi}\right)+\left(\frac{\rho_{\mathrm{s}}}{\rho_{\mathrm{w}}}\right)\left(1-\frac{\tan \alpha}{\tan \phi}\right)\right)
$$

in which $q$ is the rainfall intensity, $T$ is the soil transmissivity, $\alpha$ is the slope, $a / b$ is the cumulated area per unit of flow, $\rho_{w}$ is the density of water, $z$ is the thickness of soil, $c^{\prime}$ is the soil cohesion, $\varphi$ is the soil internal friction angle and $\rho_{s}$ is the saturated bulk density of the soil. Hence the safety factor $F_{s}$ may be then computed as follows:

$F_{s}=\frac{c^{\prime}+z \gamma_{w} \cos ^{2} \alpha-\tan \phi}{z \gamma_{s} \sin \alpha \cos \alpha}-\frac{\gamma_{w}}{\gamma_{s}} \frac{\tan \phi}{\tan \alpha}\left(\frac{h}{z}\right)$

in which $\gamma_{s}$ is the specific weight of saturated soil and $\gamma_{w}$ is the specific weight of water.

In this study, the duration of the rainfall event was fixed equal to the time necessary for the soil to reach a steady-state condition through the following relation (Papa et al., 2010):

$\tau_{\mathrm{s}}=\frac{1}{\mathrm{n}} \sum_{\mathrm{i}=1}^{\mathrm{n}} \frac{\mathrm{a}_{\mathrm{i}}}{\mathrm{b}_{\mathrm{i}}} \frac{\theta_{\mathrm{s}_{\mathrm{i}}}}{\mathrm{K}_{\mathrm{i}} \cos \alpha_{\mathrm{i}} \sin \alpha_{\mathrm{i}}}$

in which $n$ is the basin cell number, $\tau_{s}$ is the time for saturation and $\theta_{s}$ is the water content at saturation.

The rainfall intensity, corresponding to the duration time of rainfall $\left(\tau_{s}\right)$ for the different return periods, can be derived from the intensity-duration-frequency curves.

\subsection{Propagation and deposition models}

At the basin scale, the results achieved with the application of models for stability are needed to delimit landslide runout areas.

The first level of the methodology is a geometrical approach, useful for a preliminary evaluation of landslide-river interaction areas. The dfwalk model (Gamma, 1999; Hurlimann et al., 2008), which integrates the D8 flow-routing method (O'Callaghan and Mark, 1984) with the randomwalk (Monte Carlo) theory and the empirical "reach angle" model that includes correlations of travel angle and volume (Corominas, 1996), was adopted. The first is used to determine the preferential flow path, and the last is used to define the landslide runout.

The probability $P_{x y}$ was computed for each cell of the DEM using the following equation:

$P_{x y}=\frac{n_{\text {afect }}}{n_{\text {iter }}}$,

in which $n_{\text {afect }}$ is the number of flow trajectories that invaded a cell and $n_{\text {iter }}$ is the flow trajectories calculated. 


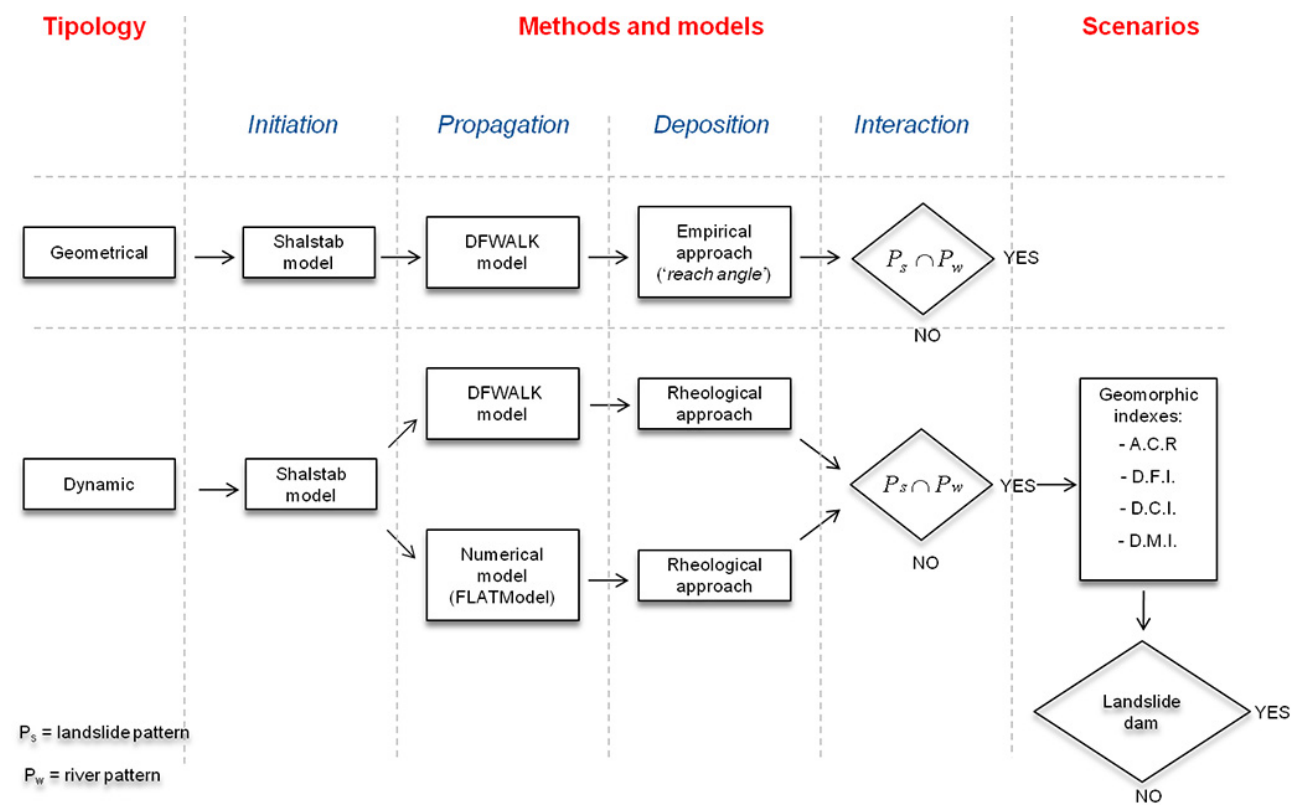

Fig. 5. Multilevel methodology to assess landslide dam hazard at basin scale and to identify potential scenarios through geometrical and dynamic approaches.

The second level, advanced, was assessed to study the process of interference in dynamic terms, quantifying the parameters of depth and velocity of the mass movement as well as the hydrodynamic parameters of the river flow.

In the first approach of this level, the dfwalk model was combined with the rheological model for the propagation of landslides, estimating the velocity in interaction cells and assuming constant thickness.

The rheological approach used in the study for the interpretation of landslide mobility was the Coulomb viscous model that is widely recognized (Coussot, 1997) as one of the most well-developed models for describing viscoplastic material properties in laminar regimes (Johnson, 1970):

$\tau=\tau_{0}+(\sigma-u) \tan \phi+\eta\left(\frac{\delta v}{\delta z}\right)^{n}$

in which $\sigma$ is the effective normal stress, $u$ is the water pressure, $\varphi$ is the friction angle, $\eta$ is the dynamic viscosity of matrix, $y$ is the depth normal to flow surface, and $n$ is the exponent.

In order to calculate the velocity deposition of the landslide, an energy equation was used:

$E_{\mathrm{cin}}+E_{\mathrm{pot}}=c t e-\Delta E$,

in which $E_{\text {cin }}$ is the kinetic energy per unit area, $E_{\text {pot }}$ is the potential energy per unit area, $\Delta E$ is the energy losses per unit area, and cte is the constant.

The second approach was the most complex method and was performed by a two-dimensional finite-volume FlatModel code (Medina et al., 2008). The model, starting from
Table 1. Main geomorphic indexes of landslide-river interference in the literature.

\begin{tabular}{lll}
\hline Author & Formula & $\begin{array}{l}\text { Condition } \\
\text { of blockage }\end{array}$ \\
\hline Swanson et al. $(1985,1986)$ & $\mathrm{ACR}=\frac{U_{\mathrm{s}}}{B_{\mathrm{w}}}$ & ACR $>100$ \\
Ermini and Casagli (2003) & $\mathrm{DFI}=\frac{U_{\mathrm{s}} \cdot W \cdot D}{Q_{T=5}}$ & $\mathrm{DFI}>1$ \\
Ermini and Casagli (2003) & $\mathrm{DCI}=\frac{U_{\mathrm{s}} \cdot W \cdot D \cdot d_{30}}{Q_{T=5} \cdot B_{\mathrm{W}}}$ & $\mathrm{DCI}>0.002$ \\
\hline
\end{tabular}

$U_{\mathrm{S}}$, landslide average velocity; $W$, landslide width; $D$, landslide depth; $B_{\mathrm{W}}$, river width; $Q_{T=5}$, discharge at $5 \mathrm{yr}$ return period; $d_{30}, 30^{\circ}$ percentile of the cumulate grain size distribution.

an estimate of the rheological properties of the materials involved and using the de Saint-Venant conservation equations of motion, allowed us to have quantitative information for velocity and thickness of landslide deposition cells. The necessary information included two raster data sets with a detailed DEM and a raster map defining the initial extension and volume of the landslide.

\subsection{Landslide and river interference approaches}

The possibility that a moving landslide could block a river depends on many geomorphic factors that involve both landslide and river dynamics at the same time. The prediction of these scenarios could be reached through deterministic approaches by the formulation of geomorphic indexes that mainly take into account geomorphic variables of both river and landslide (Table 1). These parameters are generally 


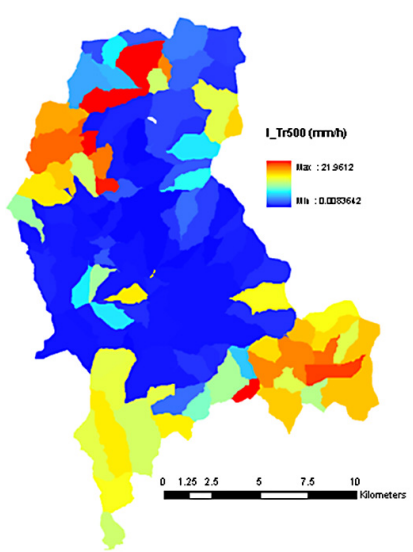

(a)

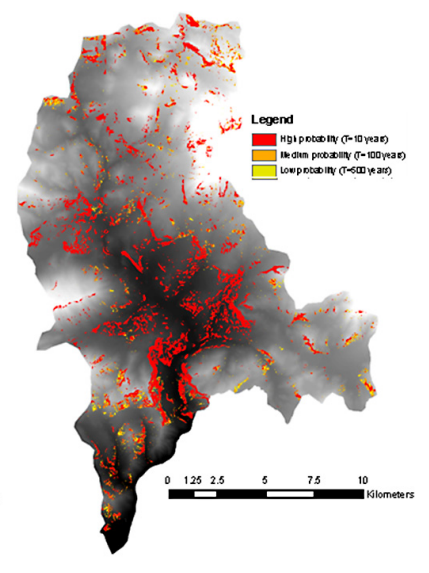

(b)
Fig. 6. (a) Example of rainfall intensity $\left(T_{r}=500 \mathrm{yr}\right)$. (b) SHALSTAB simulation results.

correlated with the landslide velocity and the channel width (Annual Constriction Ratio, Swanson et al., 1985, 1986), with the dimension of the moving mass and the river-water discharge (Dimensionless Flow Index, Ermini and Casagli, 2003), and with the grain size and texture of the blockage material (Dimensionless Constriction Index, Ermini and Casagli, 2003).

In this paper, a new geomorphic index, the Dimensionless Morpho-Invasion Index (DMI), is proposed and applied, as the result of the following expression:

$\mathrm{DMI}=\frac{\text { Landslide momentum }}{\text { River momentum }}=\frac{m_{\mathrm{s}} \cdot U_{\mathrm{s}}}{F_{\mathrm{w}} \cdot t}=\frac{2 \cdot \rho_{\mathrm{s}} \cdot U_{\mathrm{s}}^{2} \cdot V_{\mathrm{s}}}{\rho_{\mathrm{w}} \cdot g \cdot h^{2} \cdot B_{\mathrm{w}} \cdot W}$

in which $\rho_{s}$ is the material density of the landslide; $V_{S}$ is the landslide volume; $\rho_{w}$ is the water density; $g$ is the gravity acceleration; $h$ is the hydraulic level.

This approach extends the physical parameters to consider the complex description of the phenomenon, allowing us to characterize with greater accuracy the possible scenarios due to the interference between landslide and river network. The index expression uses the momentum of both landslide and river, including variables referred to the geometric, kinematic and dynamic characteristics of two systems at the same time.

In this application, it was assumed that, for values of the dimensionless parameter DMI $>1$, there was a phenomenon of total occlusion with a consequent formation of a landslide dam. This is a preliminary hypothesis that should be tested with a database of landslide dam events.

\section{Application and results}

\subsection{Triggering}

The methodology described was applied to the Noce River basin. The catchment (DEM $20 \times 20 \mathrm{~m}$ ) was studied in the

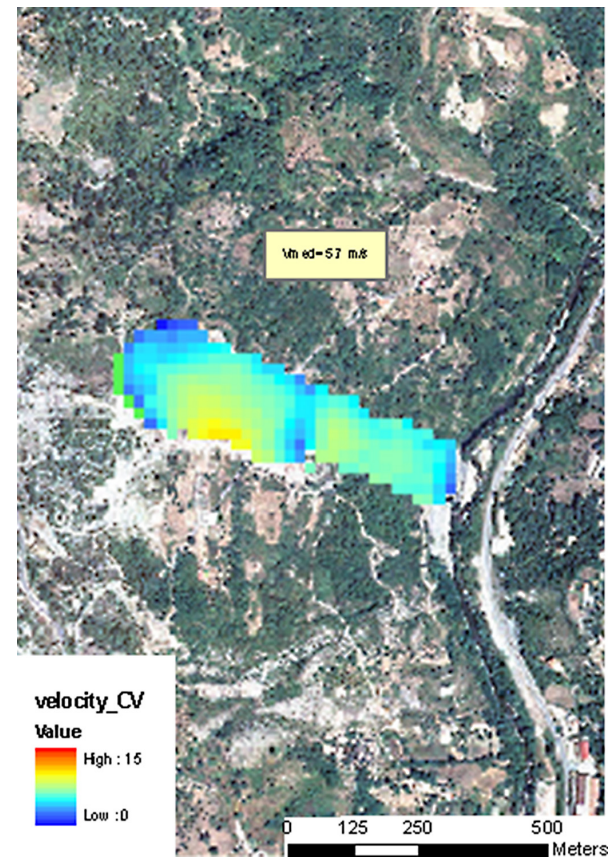

Fig. 7. Back analysis of the 1997 earthflow using the dfwalk model and the rheological approach.

hydrological behavior (Fig. 6a) and discretized into homogeneous areas according to the hydro-geological characteristics. The safety factor $F_{\mathrm{S}}$ was computed for each return period $\left(T_{r}=10,100,500\right.$ years) corresponding respectively to high, medium, and low hazard (Guzzetti et al., 1999; Carrara et al., 2008). The results (Fig. 6b) were evaluated comparing the SHALSTAB slope instability map with the location of landslide areas surveyed on the field (PAI, 2010).

\subsection{Back analysis}

In the geometrical level of the methodology, the dfwalk model was applied in combination with the empirical relationship (Corominas, 1996), calibrating geometrical parameters in order to obtain the most correct runout distance $\left(V=4.5 \times 10^{5} \mathrm{~m}^{3}, H / L_{\max }=0.24 \mathrm{rad}\right)$ :

$\tan \beta=H / L_{\max }=0.97 V^{-0.105}$

in which $\beta$ is the reach angle, $H$ is the vertical drop, $L_{\max }$ is the horizontal projection of the total runout distance and $V$ is the landslide volume.

On the dynamic level, numerical models (the dfwalk model and FlatModel) were implemented adopting, as rheological properties of material entrainment (clay marls), the back-analysis results of the landslide that occurred in 1997 in the Noce River basin (Fig. 7). In the Coulomb-Viscous model, it was assumed that the yield stress is $\tau_{y}=9 \mathrm{kPa}$, the dynamic viscosity is $\eta=0.7 \mathrm{kPa} \cdot \mathrm{s}$ and the unit weight is $\gamma=18.0 \mathrm{kN} \mathrm{m}^{-3}$. 


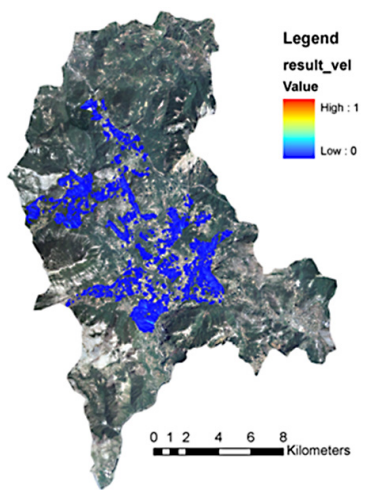

(a)

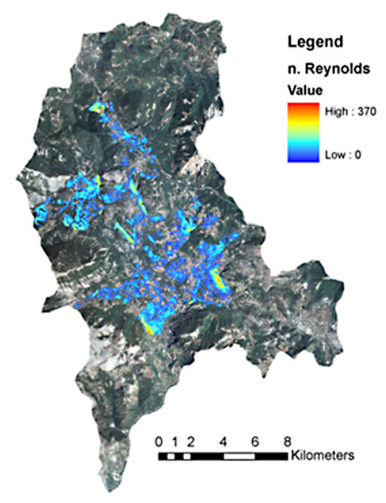

(b)
Fig. 8. Runout map (a) and Reynolds number calculation (b) using the dfwalk model.

\subsection{Propagation}

Geometrical and dynamic approaches were applied at the basin scale, as part of the clay-marl geological formations, in order to identify runout areas (Fig. 8a, b; Fig. 9a, b). The cells of landslide triggering are those classified as high hazard $\left(T_{r}=10 \mathrm{yr}\right)$ with the SHALSTAB model, considering a thickness of $4 \mathrm{~m}$ according to the head of the landslide body. In order to improve the quality of the DEM in the valley areas, that is in the zones of possible interaction between water course and hillslopes, it was modified, for a width of approximately $500 \mathrm{~m}$, through the use of the photogrammetric relief in 1:5000 scale. The results demonstrate that the use of the dfwalk model overestimates runout areas compared to the 2-D numerical FlatModel, and can be used as a precautionary approach useful for obtaining preliminary hazard maps (Fig. 10).

\subsection{Landslide-river interference}

In order to define, along river networks, the areas in which partial or total blockage of the river was possible, the raster maps of hydrodynamic $\left(Q_{T}=5_{\text {years }}, h_{T}=5_{\text {years }}\right)$ and morphological parameters $\left(B_{w}\right)$ were calculated using, respectively, the VAPI method (Gioia et al., 2008) and morphological classification. Runout areas of earth flows and river networks were overlayed in GIS (Geographic Information System) and the different geomorphic indexes were calculated in the interaction grid cells.

The application shows that it is possible to define potential landslide and river interaction areas with more complexity depending on the method used, from geometrical to dynamic ones. The spatial localization of the possible landslide dam in the catchment, evaluated with the different models, was almost in agreement and was observable mainly where the river network was narrow and confined. However, the use of dfwalk, representing the spatial probability that a cell of the river network will be invaded by a landslide and considering

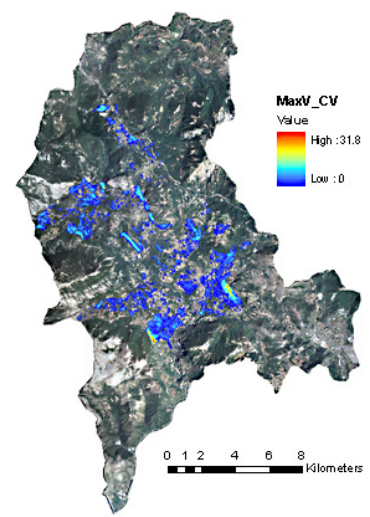

(a)

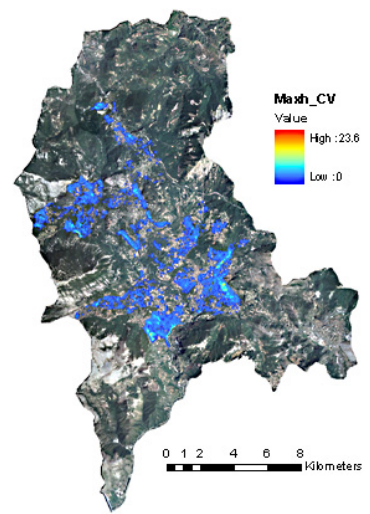

(b)
Fig. 9. Runout map with indication of velocity (a) and max depth (b) using the FlatModel.

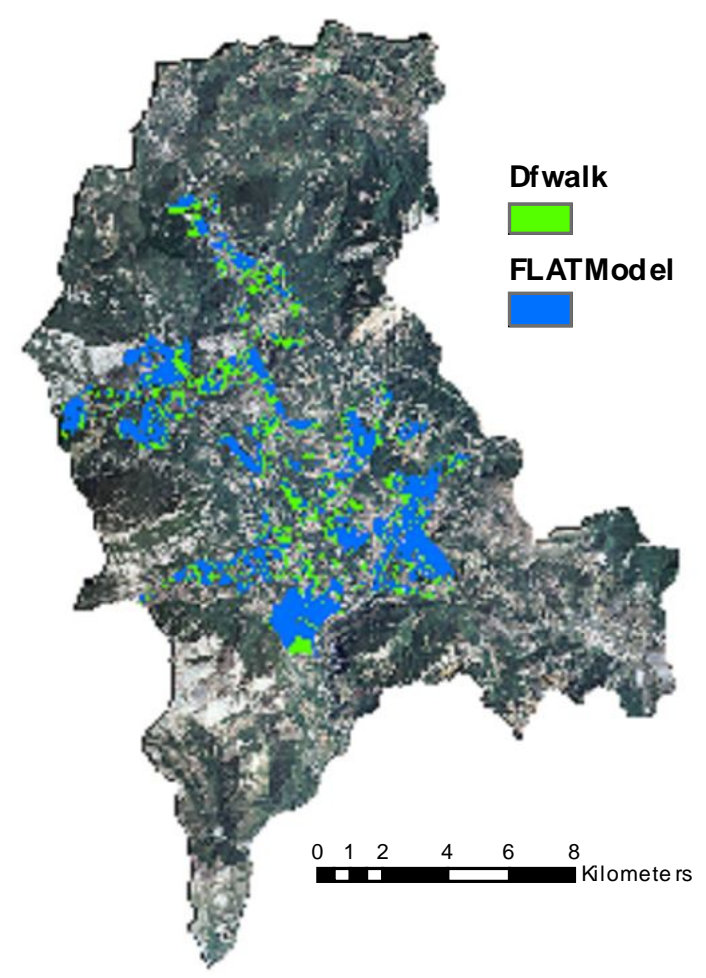

Fig. 10. Comparison of runout areas computed by the dfwalk model and the FlatModel.

the hypothesis of invariability of landslide depth along the distance travelled, can only establish a preliminary evaluation of landslide dam hazard (Figs. 11a, 12a, 13a, 14a). The maps constructed using 2-D numerical modeling (Fig. 11b, $12 \mathrm{~b}, 13 \mathrm{~b}, 14 \mathrm{~b}$ ) diverge from those created with dfwalk modeling because of the extension of the hazard zone, which is smaller (Table 2). This method should be applied to establish a detailed final hazard analysis. In both cases, the results obtained demonstrate that an accurate digital elevation 
Table 2. Summary of results using different models and methods.

\begin{tabular}{llcc}
\hline Model & Method & $\begin{array}{c}\text { Runout area } \\
\left(\mathrm{km}^{2}\right)\end{array}$ & $\begin{array}{c}\text { Interaction areas } \\
\left(\mathrm{km}^{2}\right)\end{array}$ \\
\hline \multirow{2}{*}{ dfwalk } & $\begin{array}{l}\text { Empirical: } \\
\text { Reach-angle } \\
\text { Rheological: } \\
\text { Coulomb-Viscous }\end{array}$ & 25.7 & 0.15 \\
\hline FlatModel & $\begin{array}{l}\text { Rheological: } \\
\text { Coulomb-Viscous }\end{array}$ & 19.5 & 0.13 \\
\hline
\end{tabular}

model is fundamental to obtaining better runout results. The topographic information, as well as the rheologic parameters used in the runout analysis, influence the flow trajectories of the landslide and significantly affect their deposition in the valley areas.

The analysis of the landslide dam scenarios, evaluated with deterministic approaches, can be rational with the choice of the geomorphic index applied. The results show that a detailed mapping of landslide dam hazard, with indication of incomplete damming episodes, can be achieved with an extensive characterization of the landslide and river systems that take into account additional parameters, such as the volume and grain characteristics of the landslide and the stream energy, expressed in terms of the river discharge or momentum.

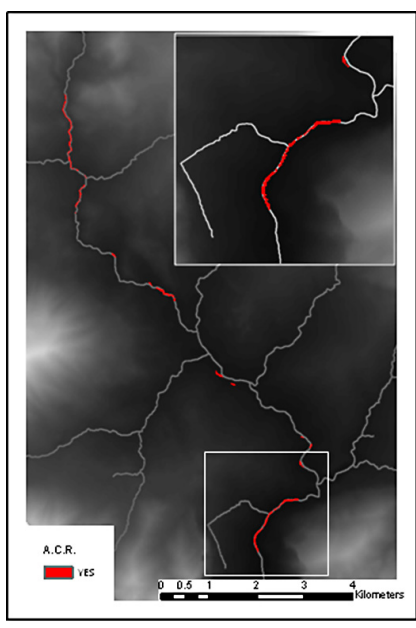

(a)

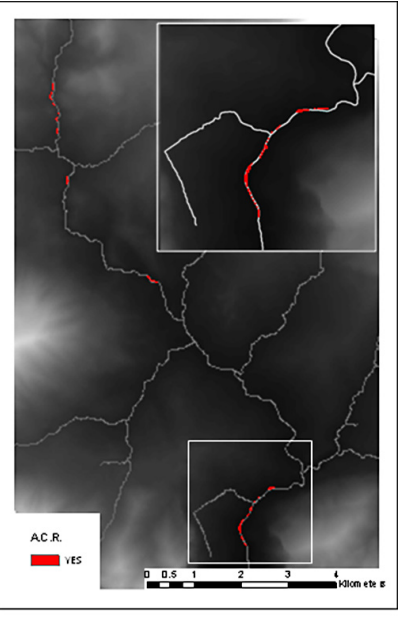

(b)
Fig. 11. Indication of the possible areas of partial (green) and total (red) river blockage according to the ACR geomorphic index using the dfwalk model (a) and the FlatModel (b).

\section{Conclusions}

Landslide dam hazard is a very complex topic because it involves composite geomorphic phenomena concerning both landslide and river systems. In this study, a methodology as-

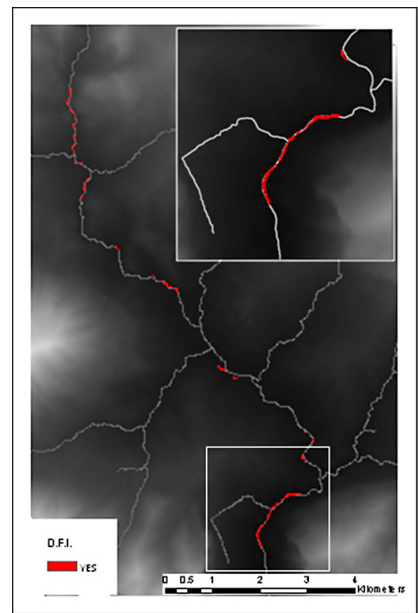

(a)

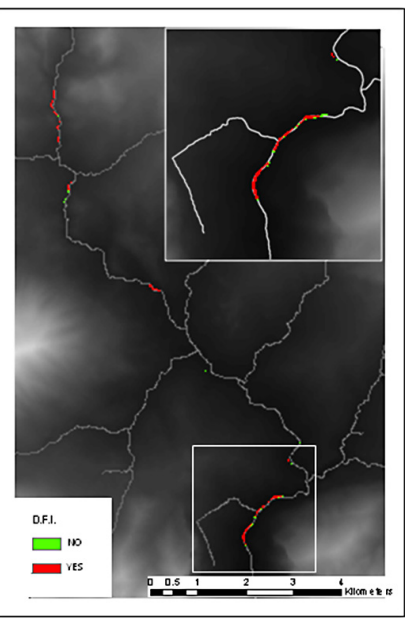

(b)
Fig. 12. Indication of the possible areas of partial (green) and total (red) river blockage according to the DFI geomorphic index using the dfwalk model (a) and the FlatModel (b).

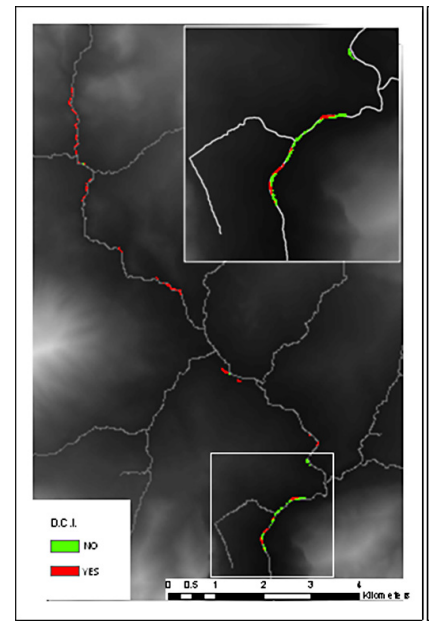

(a)

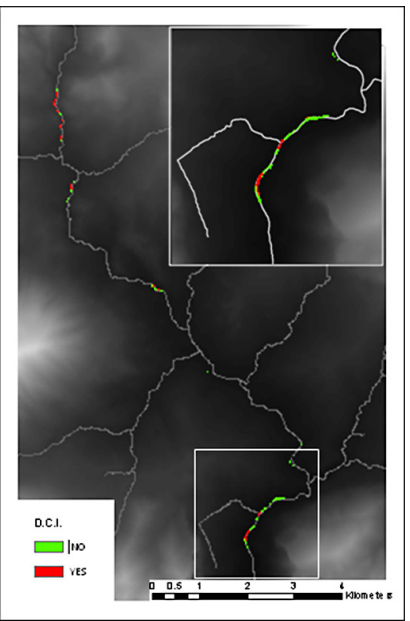

(b)
Fig. 13. Indication of the possible areas of partial (green) and total (red) river blockage according to the DCI geomorphic index using the dfwalk model (a) and the FlatModel (b).

sessed in European Research Project IMPRINTS (FP7), appropriately integrated with the use of geomorphic indexes, is applied in a case study in order to assess preliminary and final hazard maps of landslide dams in a river basin. The dfwalk model, calibrated using the empirical and Coulomb viscous rheological approaches, allowed a more plausible interpretation of the landslide studied. At the basin scale, the use of the dfwalk model in the homogeneous geological areas overestimates runout areas compared to the FlatModel 2-D numerical model, proving to be a precautionary approach useful for obtaining preliminary hazard maps. However, much work remains in calibrating these models, particularly to facilitate a 


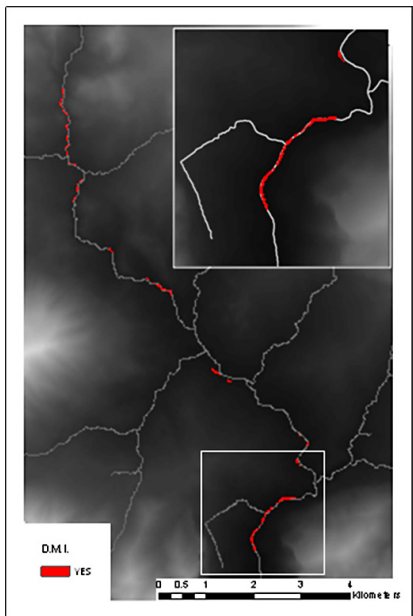

(a)

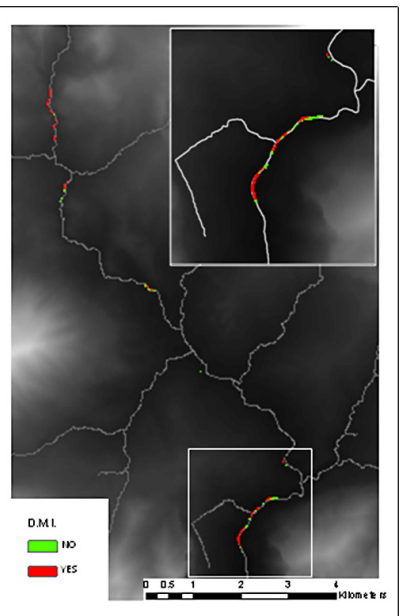

(b)
Fig. 14. Indication of the possible areas of partial (green) and total (red) river blockage according to the DMI geomorphic index using the dfwalk model (a) and the FlatModel (b).

reliable choice of the rheology of material entrainment. Concerning the issue of forecasting the possibilities of a landslide to block a river channel, the final results demonstrate that it is possible to have a prediction of a landslide dam with a more defined accuracy depending on available data, using the geometrical or dynamic approaches. The spatial localization of the possible landslide dam in the catchment is almost in agreement, while landslide dam scenarios can be sensitive to the geomorphic index applied. The geomorphic index DMI proposed, describing the interference between river network and slopes, interfaces and integrates effectively with the models used for the identification of areas of propagation because it includes the kinematic parameters as well as the geometry of the moving mass. This approach, after a preliminary validation phase using a database of landslide dams, can be a useful tool in the decision-making process associated with forecasting of dam formation and management of emergencies deriving from these events.

Acknowledgements. The authors gratefully acknowledge: the Infrastructures, OO. PP. (Public Works) and Mobility Department of Basilicata Region and Geocart Engineering Society for providing survey data and useful information for this research; the scientific coordinators and members of the European Research Project IMPRINTS (FP7) for the methodology originally developed; the Editor and the Reviewers for their critical comments and suggestions, which greatly improved the quality of the manuscript.

Edited by: M. Parise

Reviewed by: R. L. Schuster and one anonymous referee

\section{References}

Bregoli, F., Ciervo, F., Medina, V., Batemann, A., Hurlimann, M., Chevalier, G., and Papa, M.: Development of preliminary assessment tools to evaluate debris flow risks. A: XVIII International Conference on Computational Methods in Water Resources, CMWR, 1-9, 2010.

Carrara, A., Crosta, G., and Frattini, P.: Comparing models of debris-flow susceptibility in the alpine environment, Geomorphology, 94, 353-378, 2008.

Casagli, N. and Ermini, L.: Geomorphic Analysis of Landslide Dams in the Northern Apennine - Transactions, Japanese Geomorphological Union, 20-3, 219-249, 1999.

Corominas, J.: The angle of reach as a mobility index for small and large landslides, Can. Geotech. J., 33, 260-271, 1996.

Costa, J. E. and Schuster, R. L.: The formation and failure of natural dams, Geol. Soc. Am. Bull., 100, 1054-1068, 1988.

Coussot, P.: Mudflow Rheology and Dynamics. Balkema, Rotterdam, 1997.

Crosta, G. B., Chen, H., and Lee, C. F.: Replay of the 1987 Val Pola Landslide, Italian Alps, Geomorphology, 60, 127-146, 2004.

Cruden, D. M. and Varnes, D. J.: Landslide types and processes, in: Landslides Investigation and Mitigation, edited by Turner, A. K. and Schuster, R. L., National Research Council, Transportation Research Board, Special Report 247, 36-75, 1996.

Davies, T. R., Manville, V., Kunz, M., and Donadini, L.: Modelling Landslide Dam break Flood Magnitudes: Case Study., J. Hydraul. Eng., 133, 713-720, 2007.

Di Maio, C. and Sole, A.: Analisi geotecnica e idrologico-idraulica sul problema del versante in frana e degli effetti sul fiume Noce in c. da Zillona di Trecchina (Pz), Report for Basilicata Region, 2009.

Di Maio, C., Vallario, M., and Vassallo, R.: Una colata in Crete Nere a Trecchina: analisi preliminare. Incontro Annuale dei Ricercatori di Geotecnica 2009, IARG 2009, 6 pp., Roma, 2009.

Ermini, L. and Casagli, N.: Prediction of the behavior of landslide dams using a geomorphologic dimensionless index, Earth Surf. Proc. Land., 28, 31-47, 2003.

Fread, D. L.: BREACH: An Erosion Model for Earthen Dam Failures, National Weather Service, Maryland, 1991.

Gamma, P.: DFWALK-Ein Murgang-Simulationsprogramm zur Gefahrenzonierung. PhD Thesis, University of Berne, 144 pp. 1999.

Gioia, A., Iacobellis, V., Manfreda, S., and Fiorentino, M.: Runoff thresholds in derived flood frequency distributions, Hydrol. Earth Syst. Sci., 12, 1295-1307, doi:10.5194/hess-12-12952008, 2008.

Guzzetti, F., Carrara, A., Cardinali, M., and Reichenbach, P.: Landslide hazard evaluation: a review of current techniques and their application in a multi-scale study, central Italy, Geomorphology, 31, 181-216, 1999.

Hürlimann, M., Rickenmann, D., Medina, V., and Bateman, A.: Evaluation of approaches to calculate debris-flow parameters for hazard assessment, Eng. Geol., 102, 152- 163, 2008.

Johnson, A. M.: Physical processes in geology. Freeman, Cooper and Co., San Francisco, 576 pp., 1970.

Korup, O.: Geomorphometric characteristics of New Zealand landslide dams, Eng. Geol., 73, 13-35, 2004. 
Korup, O.: Geomorphic hazard assessment of landslide dams in South Westland, New Zealand: Fundamental problems and approaches, Geomorphology, 66, 167-188, 2005.

Medina, V., Bateman, A., and Hürlimann, M.: FLATModel: a 2D finite volume code for debris-flow modelling. Application to events occurred in the Eastern Pyrenees, Int. J. Sediment Res., 23, 348-360, 2008.

Montgomery, D. R. and Dietrich, W. E.: A physically based model for the topographic control on shallow landsliding, Water Resour. Res., 30, 1153-1171, 1994.

Nicoletti, P. G., Parise, M., and Miccadei E.: The Scanno rock avalanche (Abruzzi, south-central Italy), Bollettino della Società Geologica Italiana, 112, 523-535, 1993.

Nicoletti P. G. and Parise M.: Seven landslides dams of old seismic origin in southeastern Sicily (Italy), Geomorphology, 46, 203$222,2002$.

O'Callaghan, J. F. and Mark, D. M.: The extraction of drainage networks from digital elevation data. Computer Vision, Graphics and Image Processing, 28, 323-344, 1984.
PAI: Piano Stralcio di Bacino per l'Assetto Idrogeologico (PAI). Autorità di Bacino regionale, Regione Basilicata, 2010.

Papa, M.: Development of preliminary assessment tools to evaluate debris flow risks. A: XVIII International Conference on Computational Methods in Water Resources, CMWR, 1-9, 2010.

Schuster, R. L., and Costa J. E.: A perspective on landslide dams: In Schuster, R.L., ed., Landslide Dams - Processes, Risk, and Mitigation: Geotechnical Special Publication No. 3, American Society of Civil Engineers., 1-20, 1986.

Swanson, F. J., Graham, R. L., and Grant, G. E.: Some effects of Slope Movements on River Channel. Proceedings of the International Symposium on Erosion, Debris Flow and Disaster Prevention, Tsukuba, Japan, 273-27, 1985.

Swanson, F. J., Oyagi, N., and Tominaga, M.: Landslide dams in Japan, in: Landslide dams: Processes risk and mitigation, edited by: Schuster, R. L., American Society of Civil Engineers Geotechnical Special Publication, 3, 131-145, 1986. 